\title{
THE EFFECT OF 2-BUTYL-CYANOACRYLATE ADHESIVE IN OSTEOTOMIES AND BONE GRAFTS IN RABBITS: MACROSCOPIC AND RADIOGRAPHIC CHARACTERISTICS
}

Mário Sérgio Viana Xavier' ${ }^{1}$, Vilnei Mattioli Leite ${ }^{2}$

\begin{abstract}
Objective: To evaluate the effect of butyl-2-cyanoacrylate tissue adhesive in osteotomies and bone grafts, with regard to macroscopic and radiographic characteristics. Methods: Forty-eight rabbits were used, randomly divided into four groups of 12 animals, with observation periods of two, four, eight and 16 weeks. Both thoracic limbs were operated in each animal and two osteotomies were performed in each of the radii, withdrawing a bone fragment (bone graft) of $1 \mathrm{~cm}$ in length. On one side, the bone graft was then replaced and a drop of adhesive was applied to each of the osteotomies. On the other side, the same procedure was performed without applying the adhesive. The rejection level for the nullity hypothesis was set at $0.05 \%$ or $5 \%$. Results: Blue marks were present in all the surgical
\end{abstract}

specimens in which adhesive was applied. From the fourth week onwards, there was absence of movement of the bone grafts with adhesive and control. In group A, in the proximal osteotomies with adhesive, there was less deviation of the bone graft $(p=0.02)$. In group $C$, the union $(p=0.03)$ and the integration of the bone graft $(p=0.02)$ were better in the proximal osteotomies with adhesive. Conclusions: The adhesive was not completely metabolized within 16 weeks. There was clinical consolidation of the osteotomies within four weeks. The adhesive stabilized the bone graft within the first weeks and did not interfere with the consolidation of the osteotomies, or the integration of the bone graft in radiographic observations.

Keywords - Tissue Adhesives; Enbucrilate; Osteotomy; Polymerization; Bone Transplantation; Osseointegration

\section{INTRODUCTION}

In comminutive fractures of the diaphysis of long bones, the cortical bone fragments behave like autologous grafts and often require internal fixation ${ }^{(1)}$. This leads to a need for two surgical procedures: firstly, to reduce the factures and place implants such as plates, screws, steel wires, pins or intramedullary nails; secondly, to remove the implant ${ }^{(2)}$.

Furthermore, some authors have reported a variety of complications from using metal implants, such as extrusion of the material, palpation through the skin, bone growth disorders, bone reabsorption, osteoporosis and interference with computed tomography and magnetic resonance imaging techniques ${ }^{(3)}$.
The cost of metal implants is also an important factor to be considered. Their high price makes fracture treatment expensive, in addition to the longer duration of operations involving metal implants, with their consequent additional costs. Therefore, it would be desirable to have a fixation method that would stabilize bone fragments at a lower cost, without the complications inherent to using metal implants ${ }^{(4)}$.

Cyanoacrylates are a group of fast-polymerization adhesives that started to be used in surgery in the $1960 \mathrm{~s}^{(5)}$. These would make it possible to use this method, since they are absorbable, biocompatible, easy to use, cost-cost, sterilizable in ethylene oxide and radiotransparent, and have the property of adhering to wet surfaces ${ }^{(6)}$.

\footnotetext{
1 - Titular Professor of Orthopedics and Traumatology, UNIVÁS-FACIMPA, Pouso Alegre, MG, Brazil.

2 - Full Professor in the Department of Orthopedics, UNIFESP, São Paulo, SP, Brazil.

Work performed jointly at the University of Vale do Sapucaí and the School of Health Sciences of Pouso Alegre (UNIVÁS-FACIMPA).

Correspondence: Avenida Prefeito Sapucaí 68, Medicina, 37550-000 Pouso Alegre, MG. E-mail: mario.xavier@uol.com.br

Work received for publication: October 3, 2011; accepted for publication: January 13, 2012.
}

The authors declare that there was no conflict of interest in conducting this work 
Since the potential use of cyanoacrylates for treating fractures has received little attention, it was decided to study the effect of butyl-2-cyanoacrylate in osteotomies and bone grafts, from the macroscopic and radiographic points of view.

\section{METHODS}

Forty-eight adult male New Zealand White rabbits (Oryctolagus cuniculus) were used, with body weights ranging from 2,500 to 4,000 g. They came from the vivarium of FACIMPA, and were housed in individual cages, with natural illumination and room temperature, and were fed with commercial feed that was appropriate for the species, ad libitum. The animals were allowed a two-week adaptation period. The experiment was conducted at the Experimental Surgery Laboratory of the Department of Clinical and Surgical Medicine of FACIMPA.

Four groups of 12 animals each were formed randomly. They were named A, B, C and D, according to the lengths of the observation periods after the surgical procedure, which were respectively two, four, eight and sixteen weeks.

The ethical recommendations of the Council for International Organizations of Medical Sciences (CIOMS) and the principles of the Brazilian College of Animal Experiments were followed. The study was approved by the Research Ethics Committee of the Federal University of São Paulo/Hospital São Paulo (Ref. CEP no. 436/00).

Pre-anesthesia was accomplished using $1 \%$ acepromazine, intramuscularly (IM) at a dose of $2 \mathrm{mg} / \mathrm{kg}$. Forty minutes later, the animals were anesthetized using ketamine hydrochloride at a dose of $40 \mathrm{mg} / \mathrm{kg}$ and $2 \%$ xylazine hydrochloride at a dose of $8 \mathrm{mg} / \mathrm{kg}$, injected IM.

One $\mathrm{ml}$ of $1 \%$ lidocaine hydrochloride was infiltrated into the lateral dorsal region of the distal third of the forearms and then a straight incision of $3 \mathrm{~cm}$ in length was made in the skin. The common extensor tendons of the fingers were pushed away to one side and the radial extensor of the carpus to the other side, thereby exposing the distal half of the radius through extraperiosteal dissection. A fragment of the radius of $1 \mathrm{~cm}$ in length was removed as a bone graft, after two complete transverse osteotomies using a rotary saw with a steel disc, attached via an adaptor to a batteryoperated drilling device (Dremel ${ }^{\circledR}$ model 750), with a velocity of 5,000 rotations per minute, under continual irrigation with $0.9 \%$ physiological serum. The distal osteotomy was performed $1.5 \mathrm{~cm}$ proximally to the radiocarpal joint. Following this, the fragment of the radius was replaced in this location as an autologous cortical graft, without removing the periosteum. A drop of blue-colored butyl-2-cyanoacrylate tissue adhesive (Histoacryl ${ }^{\circledR}$, B. Braum, Melsungen AG, Germany) was placed on each osteotomy, in the direction from dorsal to ventral, by squeezing the original packaging, which was provided with a capillary tip (Figure 1).

In the other thoracic limb, the bone graft was simply replaced at the same location.

The epidermis was sutured using simple stitches of 4-0 monofilament nylon.

The side on which the tissue adhesive was used was alternated: thus, if the adhesive was used on the right thoracic limb in one animal of a given group, it would be used on the left limb in the next animal of the same group.

The animals were observed every day for the first week and then once a week until the date of sacrifice. If any animal presented signs of infection with a compromised general state or fracture, it was sacrificed and replaced, in order to avoid distress and to maintain the standardization of the sample.

At the predetermined times, the animals were anesthetized and the operative wounds were examined with regard to the presence of dehiscence, infection or fistula.

The animals were sacrificed by means of an intracardiac injection of $3 \mathrm{ml}$ of $10 \%$ potassium chloride $(\mathrm{KCl})$. The forearms were then removed, the soft

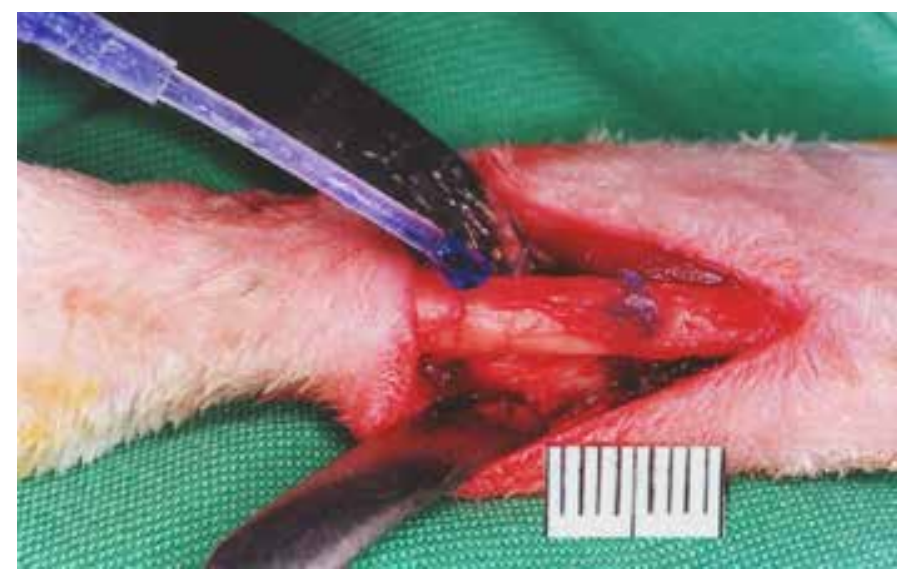

Figure 1 - Surgical procedure: after replacement of the bone graft, showing a drop of adhesive placed on the distal osteotomy, and already polymerized on the proximal osteotomy. 
tissue was also removed and the surgical specimens were observed with regard to the presence of deformity and blue marks. The stability of the bone graft was tested by observing its movement upon manipulation using anatomical tweezers.

The surgical specimens from the same animal were labeled and radiographed in pairs, in anteroposterior (AP) and lateromedial (LM) positioning, at a standard distance of $100 \mathrm{~cm}$.

Scoring systems were established for the displacement of the bone graft, union of the osteotomies and integration of the bone graft at the proximal and distal osteotomies, in the AP and LM radiographic views. The worse result prevailed for each item, i.e. if the displacement of the bone graft at the proximal osteotomy on the right side in AP view was 0 and it was 1 in LM view, the score of 0 prevailed. Presence or absence of fractures in the bone graft or in the ulna was also analyzed in the two radiographic views. The scoring was done in the increasing direction, from the worst result to the best result, for all the items.

Displacement of the bone graft: 0 - greater than $50 \%$ of the osteotomy surface; 1 - up to $50 \%$ of the osteotomy surface; 2 - aligned.

Union of the osteotomies: 0 - continuity solution on the osteotomy surface greater than $50 \% ; 1$ - continuity solution on the osteotomy surface up to $50 \% ; 2-\mathrm{ab}$ sence of continuity solution on the osteotomy surface. Integration of the bone graft: 0 - absence of integration; 1 - remodeling of the intramedullary canal; 2 - total remodeling of the cortical bone.

Fractures of the bone graft and ulna: 0 - present; 1 - absent.

The radiographs were evaluated by three independent observers at different times and without knowledge of the animal group (Figure 2).

\section{STATISTICAL METHOD}

To analyze the results, the following tests were performed: analysis of variance to study the homogeneity of the animals' weights before the surgery, between the four groups; $t$ test to compare the animals' weights at the beginning and end of each group; Friedman's analysis of variance to compare the values of the variables measured by the three observers who participated in the experiment (this analysis was applied separately for the results observed among the limbs with adhesive and among the control limbs);

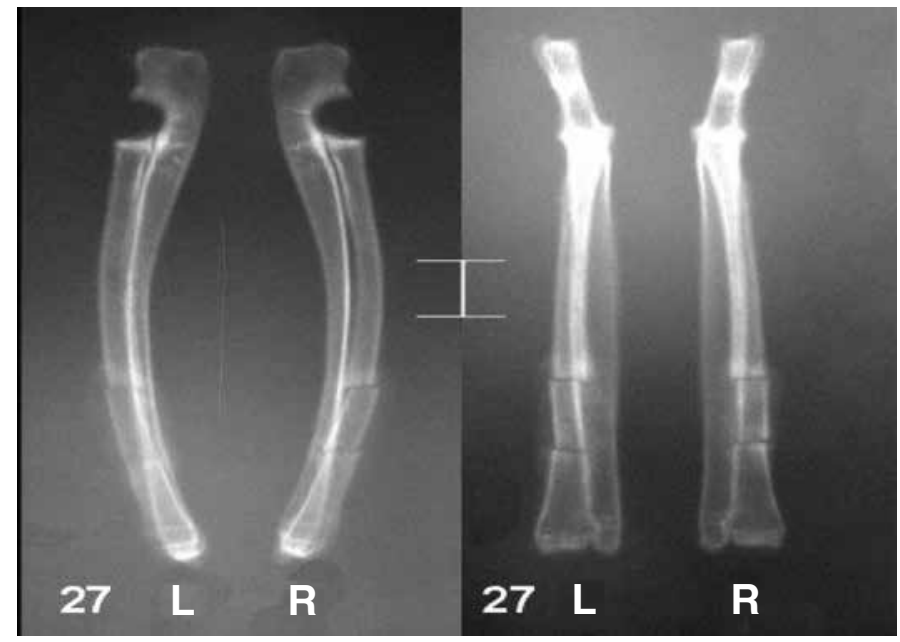

Figure 2 - Radiograph showing bone grafts (BG) misaligned by up to $50 \%$ on the surface of the proximal osteotomy (PO) and distal osteotomy (DO) on the right side $(\mathrm{R})$ and aligned in the $\mathrm{DO}$ on the left side (L); continuity solution greater than $50 \%$ on the surfaces of the PO and DO on the R and $\mathrm{L}$ sides; absence of integration of the $\mathrm{BG}$; and absence of fractures (rabbit no. 27 , group $A ; R=$ control and $L=$ adhesive).

and Wilcoxon's test with the aim of comparing the results observed with and without the adhesive for each rabbit.

The rejection level for the nullity hypothesis was set at 0.05 or $5 \%(\alpha \leq 0.05)$, and significant values were indicated using boldface type.

\section{RESULTS}

The animals' weights compared between the four groups before the operation were shown to be homogenous.

There was no significant difference in weight from before the operation to the time of sacrifice between the groups, or in the $\Delta \%$ of the animals' weights between the groups.

There was no significant difference between the side with the adhesive and the control side, with regard to dehiscence, infection, fistula, deformity of the surgical specimen or stability of the bone graft.

The presence of blue marks remaining from the adhesive was observed in all the surgical specimens in which the adhesive had been used, and these marks were absent from all the controls.

Since there was no statistically significant difference between the three observers in the analyses on the radiographs, in relation to union of the osteotomies, displacement and bone graft integration, it was decided to use the scores from observer 3 , since these were the scores that came closest to the best result expected. 
In group A, in the proximal osteotomies with adhesive, there was less deviation of the bone graft. In the other groups, there was no significant difference between the adhesive and control limbs.

In group $\mathrm{C}$, the bone union was better in the proximal osteotomies with adhesive. In the other groups, it was observed that the scoring relating to bone union increased with time, but without any statistically significant difference between the adhesive and control limbs.

In group $\mathrm{C}$, the bone graft integration was better in the proximal osteotomies with adhesive. In groups $\mathrm{A}$ and $\mathrm{B}$, no bone graft integration occurred in most of the osteotomies.

Consolidation and integration of the bone graft in the adhesive and control limbs occurred in most of the osteotomies before the $16^{\text {th }}$ week of observation.

No fractures of the bone graft occurred in any of the animals.

There was no significant difference between the side with adhesive and the control side in relation to ulnar fractures (Tables 1, 2, 3, 4 and 5).

\section{DISCUSSION}

Through the osteotomies, it was sought to simulate comminutive fractures with defined comminution pattern and soft-tissue injury, and with established osteotomy sites and distance between them. Complete displacement of the bone segment was accomplished: the segment was removed and then replaced in the original site. The bone fragment thus formed an autologous cortical bone graft and the osteotomies could be considered to be fractures. The osteotomies were performed in the region of the cortical bone and the site was irrigated with physiological serum in order to avoid heating and bone necrosis ${ }^{(7,8)}$. A previous study using bone tissue from a cadaver showed that the rigidity of butyl-2-cyanoacrylate adhesive is five times greater on cortical bone than on spongy bone and that it exceeds the minimum value for use as a bone adhesive ${ }^{(9)}$.

The periosteum was maintained on the bone graft and at the ends of the bone because it was found in a previous study that if it was removed, replacement of the dead cells of the cortical bone in the graft and union of the osteotomies was much slower than in a group with periosteum ${ }^{(10)}$. In another experimental study, it was shown that the periosteum made a $30 \%$
Table 1 - Proximal and distal osteotomies according to three observers' readings of displacement, radiographic union and integration of bone grafts with adhesive and without adhesive (control), in group A (2 weeks).

\begin{tabular}{|c|c|c|c|c|c|}
\hline \multicolumn{2}{|c|}{$\begin{array}{l}\text { Proximal with } \\
\text { adhesive }\end{array}$} & \multirow{2}{*}{\begin{tabular}{|c|} 
Obs. 1 \\
1.42 \\
\end{tabular}} & \multirow{2}{*}{\begin{tabular}{|c|} 
Obs. 2 \\
1.33 \\
\end{tabular}} & \multirow{2}{*}{\begin{tabular}{|c|} 
Obs. 3 \\
1.25 \\
\end{tabular}} & \multirow{3}{*}{$\begin{array}{c}\begin{array}{c}\text { Friedman's analysis } \\
\text { of variance }\end{array} \\
x^{2}=2.00 \\
(p=0.368) N S\end{array}$} \\
\hline \multirow{2}{*}{ Displacement } & $x^{-}$ & & & & \\
\hline & Mi & 1 & 1 & 1 & \\
\hline \multirow{2}{*}{$\begin{array}{l}\text { Radiographic } \\
\text { union }\end{array}$} & $x^{-}$ & 0 & 0 & 0 & \multirow{4}{*}{ No need for analysis } \\
\hline & Mi & 0 & 0 & 0 & \\
\hline \multirow{2}{*}{ Integration } & $x^{-}$ & 0 & 0 & 0 & \\
\hline & Mi & 0 & 0 & 0 & \\
\hline
\end{tabular}

Proximal control

\begin{tabular}{|c|c|c|c|c|c|}
\hline \multirow{2}{*}{ Displacement } & $x^{-}$ & 0.83 & 0.92 & 0.67 & \multirow{2}{*}{$\begin{array}{c}x^{2}=3.50 \\
(p=0.174) N S\end{array}$} \\
\hline & $\mathrm{Mi}$ & 1 & 1 & 1 & \\
\hline \multirow{2}{*}{$\begin{array}{c}\text { Radiographic } \\
\text { union }\end{array}$} & $x^{-}$ & 0 & 0 & 0 & \multirow{4}{*}{ No need for analysis } \\
\hline & $\mathrm{Mi}$ & 0 & 0 & 0 & \\
\hline \multirow{2}{*}{ Integration } & $x^{-}$ & 0 & 0 & 0 & \\
\hline & $\mathrm{Mi}$ & 0 & 0 & 0 & \\
\hline
\end{tabular}

Distal with adhesive

\begin{tabular}{|c|c|c|c|c|c|}
\hline \multirow{2}{*}{ Displacement } & $x^{-}$ & 1.83 & 1.75 & 1.83 & \multirow{2}{*}{$\begin{array}{c}x^{2}=2.00 \\
(p=0.368) N S\end{array}$} \\
\hline & $\mathrm{Mi}$ & 2 & 2 & 2 & \\
\hline \multirow{2}{*}{$\begin{array}{c}\text { Radiographic } \\
\text { union }\end{array}$} & $x^{-}$ & 0 & 0.08 & 0.33 & \multirow{2}{*}{$\begin{array}{c}x^{2}=5.60 \\
(p=0.06) \text { NS }\end{array}$} \\
\hline & $\mathrm{Mi}$ & 0 & 0 & 0 & \\
\hline \multirow{2}{*}{ Integration } & $x^{-}$ & 0 & 0 & 0 & \multirow{2}{*}{$\begin{array}{c}x^{2}=3.71 \\
(p=0.156) N S\end{array}$} \\
\hline & $\mathrm{Mi}$ & 0 & 0 & 0 & \\
\hline
\end{tabular}

Distal control

\begin{tabular}{|c|c|c|c|c|c|}
\hline \multirow{2}{*}{ Displacement } & $x^{-}$ & 1.5 & 1.5 & 1.5 & \multirow{2}{*}{$\begin{array}{c}x^{2}=0.00 \\
(p=1.00) N S\end{array}$} \\
\hline & $\mathrm{Mi}$ & 1.5 & 1.5 & 1.5 & \\
\hline \multirow{2}{*}{$\begin{array}{c}\text { Radiographic } \\
\text { union }\end{array}$} & $x^{-}$ & 0 & 0 & 0 & \multirow{2}{*}{ No need for analysis } \\
\hline & $\mathrm{Mi}$ & 0 & 0 & 0 & \\
\hline \multirow{2}{*}{ Integration } & $x^{-}$ & 0 & 0 & 0.08 & \multirow{2}{*}{$\begin{array}{c}x^{2}=2.00 \\
(p=0.368) N S\end{array}$} \\
\hline & $\mathrm{Mi}$ & 0 & 0 & 0 & \\
\hline
\end{tabular}

Legend: $x$-: mean - Mi: median - NS: not significant

Sources: DOT. UNIFESP-EPM UNIVÁS-FACIMPA.

contribution towards formation of new bone in the bone graft $^{(11)}$.

The control in the present study was in the same animal, because the normal variation in biological activity (reabsorption, apposition, porosity and new bone formation) in the same segment of the skeleton in different animals is so large that using different animals as controls presents limitations. It is very important to compare experimental and control bone grafts in the same animal, because if one evolves poorly, the other will also evolve in this manner ${ }^{(12)}$. It was decided to vary the side on which the operative technique under examination (i.e. osteotomy with adhesive) was used in order to avoid biased sampling.

The bone graft was replaced in the original location, thus maintaining well adapted proximal and distal surfaces. Two factors are important in obtaining union between the bone ends and the bone graft: perfect 
Table 2 - Proximal and distal osteotomies according to three observers' readings of displacement, radiographic union and integration of bone grafts with adhesive and without adhesive (control), in group B (4 weeks).

\begin{tabular}{|c|c|c|c|c|c|}
\hline \multicolumn{2}{|c|}{$\begin{array}{l}\text { Proximal with } \\
\text { adhesive }\end{array}$} & \multirow{2}{*}{\begin{tabular}{|c|} 
Obs. 1 \\
1.33 \\
\end{tabular}} & \multirow{2}{*}{\begin{tabular}{|c|} 
Obs. 2 \\
1.42 \\
\end{tabular}} & \multirow{2}{*}{\begin{tabular}{|c|} 
Obs. 3 \\
1.42 \\
\end{tabular}} & \multirow{2}{*}{\begin{tabular}{|c}
$\begin{array}{c}\text { Friedman's analysis } \\
\text { of variance }\end{array}$ \\
$x^{2}=0.67$
\end{tabular}} \\
\hline \multirow{2}{*}{ Displacement } & $x^{-}$ & & & & \\
\hline & $\mathrm{Mi}$ & 1 & 1 & 1 & \\
\hline \multirow{2}{*}{$\begin{array}{l}\text { Radiographic } \\
\text { union }\end{array}$} & $x^{-}$ & 0 & 0 & 0 & \multirow{4}{*}{ No need for analysis } \\
\hline & $\mathrm{Mi}$ & 0 & 0 & 0 & \\
\hline \multirow{2}{*}{ Integration } & $\mathrm{x}^{-}$ & 0 & 0 & 0 & \\
\hline & & 0 & 0 & 0 & \\
\hline
\end{tabular}

Proximal control

\begin{tabular}{|c|c|c|c|c|c|}
\hline \multirow{2}{*}{ Displacement } & $x^{-}$ & 1.42 & 1.5 & 1.58 & \multirow{2}{*}{$\begin{array}{c}x^{2}=1.20 \\
(p=0.549) N S\end{array}$} \\
\hline & Mi & 1 & 2 & 2 & \\
\hline \multirow{2}{*}{$\begin{array}{c}\text { Radiographic } \\
\text { union }\end{array}$} & $x^{-}$ & 0 & 0 & 0 & \multirow{2}{*}{ No need for analysis } \\
\hline & $\mathrm{Mi}$ & 0 & 0 & 0 & \\
\hline \multirow{2}{*}{ Integration } & $x^{-}$ & 0 & 0 & 0.08 & \multirow{2}{*}{$\begin{array}{c}x^{2}=2.00 \\
(p=0.368) N S\end{array}$} \\
\hline & & 0 & 0 & 0 & \\
\hline
\end{tabular}

\begin{tabular}{|c|c|c|c|c|c|}
\hline \multicolumn{6}{|c|}{ Distal with adhesive } \\
\hline \multirow{2}{*}{ Displacement } & $x^{-}$ & 1.75 & 1.92 & 1.92 & \multirow{2}{*}{$\begin{array}{c}x^{2}=2.00 \\
(p=0.368) N S\end{array}$} \\
\hline & Mi & 2 & 2 & 2 & \\
\hline \multirow{2}{*}{$\begin{array}{l}\text { Radiographic } \\
\text { union }\end{array}$} & $x^{-}$ & 0.17 & 0.25 & 0.33 & \multirow{2}{*}{$\begin{array}{c}x^{2}=2.00 \\
(p=0.368) N S\end{array}$} \\
\hline & $\mathrm{Mi}$ & 0 & 0 & 0 & \\
\hline \multirow{2}{*}{ Integration } & $x^{-}$ & 0 & 0.25 & 0.25 & \multirow{2}{*}{$\begin{array}{c}x^{2}=3.80 \\
(p=0.150) N S\end{array}$} \\
\hline & & 0 & 0 & 0 & \\
\hline
\end{tabular}

\section{Distal control}

\begin{tabular}{c|c|c|c|c|c}
\hline \multirow{2}{*}{ Displacement } & $\mathrm{x}^{-}$ & 1.58 & 1.67 & 1.75 & \multirow{2}{*}{$\begin{array}{c}\mathrm{x}^{2}=2.00 \\
(\mathrm{p}=0.368) \mathrm{NS}\end{array}$} \\
\cline { 2 - 5 } $\begin{array}{c}\text { Radiographic } \\
\text { union }\end{array}$ & $\mathrm{Mi}$ & 2 & 2 & 2 & $\mathrm{x}$ \\
\cline { 2 - 5 } & $\mathrm{Mi}$ & 0.25 & 0.33 & 0.67 & \multirow{2}{*}{$\begin{array}{c}\mathrm{x}^{2}=7.538 \text { Obs. } \\
3>1 \mathrm{e} 2(\mathrm{p}=0.023)\end{array}$} \\
\hline \multirow{2}{*}{\begin{tabular}{c} 
Integration \\
\cline { 2 - 5 }
\end{tabular}} & $\mathrm{x}^{-}$ & 0 & 0.33 & 0.33 & $\begin{array}{c}\mathrm{x}^{2}=5.69 \\
(\mathrm{p}=0.058) \mathrm{NS}\end{array}$ \\
\cline { 2 - 5 }
\end{tabular}

Legend: $x$-: mean - Mi: median - NS: not significant Sources: DOT. UNIFESP-EPM UNIVÁS-FACIMPA.

adaptation and immobilization. When the placement of the graft is perfect, muscle action produces considerable tension that forces one bone structure against the other, thus functioning as a powerful stimulus for osteogenesis, both in the graft and in the bone ends. The quantity of bone callus that forms is small and the transformation into bone is faster ${ }^{(10,13)}$.

The adhesive butyl-2-cyanoacrylate was chosen because it presents excellent adhesiveness, sterility and elasticity and low toxicity to tissues; does not induce cell neoplasia; has rapid polymerization; is easy to apply to organs of animals of different species; and is eliminated through the normal excretion routes, i.e. urine and feces, and probably also through the respiratory system ${ }^{(9,14-18)}$. Another important factor in choosing butyl-2-cyanoacrylate is that it has already been used in humans, in some European countries and in Canada, without reports of toxic effects ${ }^{(4,19)}$.
Table 3 - Proximal and distal osteotomies according to three observers' readings of displacement, radiographic union and integration of bone grafts with adhesive and without adhesive (control), in group C (8 weeks).

\begin{tabular}{|c|c|c|c|c|c|}
\hline \multicolumn{2}{|c|}{$\begin{array}{l}\text { Proximal with } \\
\text { adhesive }\end{array}$} & \multirow{2}{*}{\begin{tabular}{|c|} 
Obs. 1 \\
1.42 \\
\end{tabular}} & \multirow{2}{*}{\begin{tabular}{|c|} 
Obs. 2 \\
1.5 \\
\end{tabular}} & \multirow{2}{*}{\begin{tabular}{|c|} 
Obs. 3 \\
1.5 \\
\end{tabular}} & \multirow{2}{*}{\begin{tabular}{|c|}
$\begin{array}{c}\text { Friedman's analysis } \\
\text { of variance }\end{array}$ \\
$x^{2}=0.50$ \\
\end{tabular}} \\
\hline \multirow{2}{*}{ Displacement } & $x^{-}$ & & & & \\
\hline & $\mathrm{Mi}$ & 2 & 2 & 2 & \\
\hline \multirow{2}{*}{$\begin{array}{l}\text { Radiographic } \\
\text { union }\end{array}$} & $x^{-}$ & 0.33 & 1 & 1.33 & \multirow{2}{*}{$\begin{array}{c}x^{2}=12.60 \text { Obs. } \\
3>1 \text { e } 2(p=0.002)\end{array}$} \\
\hline & $\mathrm{Mi}$ & 0 & 1 & 2 & \\
\hline \multirow{2}{*}{ Integration } & $x^{-}$ & 0.33 & 1 & 0.92 & \multirow{2}{*}{$\begin{array}{c}x^{2}=8.96 \text { Obs. } \\
3>1 \text { e } 2(p=0.011)\end{array}$} \\
\hline & & 0 & 1 & 1 & \\
\hline
\end{tabular}

Proximal control

\begin{tabular}{|c|c|c|c|c|c|}
\hline \multirow{2}{*}{ Displacement } & $x^{-}$ & 1.17 & 1.25 & 1.17 & \multirow{2}{*}{$\begin{array}{c}x^{2}=0.67 \\
(p=0.717) \text { NS }\end{array}$} \\
\hline & Mi & 1 & 1 & 1 & \\
\hline \multirow{2}{*}{$\begin{array}{c}\text { Radiographic } \\
\text { union }\end{array}$} & $x^{-}$ & 0.08 & 0.67 & 0.58 & \multirow{2}{*}{$\begin{array}{c}x^{2}=8.32 \text { Obs. } \\
2 \text { e } 3>1(p=0.016)\end{array}$} \\
\hline & $\mathrm{Mi}$ & 0 & 0.5 & 0 & \\
\hline \multirow{2}{*}{ Integration } & $x^{-}$ & 0.5 & 0.67 & 0.5 & \multirow{2}{*}{$\begin{array}{c}x^{2}=1.60 \\
(p=0.449) N S\end{array}$} \\
\hline & & 1 & 1 & 0.5 & \\
\hline
\end{tabular}

\begin{tabular}{|c|c|c|c|c|c|}
\hline \multicolumn{6}{|c|}{ Distal with adhesive } \\
\hline \multirow{2}{*}{ Displacement } & $x^{-}$ & 1.83 & 1.92 & 1.92 & \multirow{2}{*}{$\begin{array}{c}x^{2}=2.00 \\
(p=0.368) N S\end{array}$} \\
\hline & $\mathrm{Mi}$ & 2 & 2 & 2 & \\
\hline \multirow{2}{*}{$\begin{array}{l}\text { Radiographic } \\
\text { union }\end{array}$} & $x^{-}$ & 0.75 & 1.08 & 1.42 & \multirow{2}{*}{$\begin{array}{c}x^{2}=7.28 \text { Obs. } \\
3>1 \text { e } 2(p=0.026)\end{array}$} \\
\hline & Mi & 0.5 & 1 & 2 & \\
\hline \multirow{2}{*}{ Integration } & $x^{-}$ & 0.75 & 1.25 & 1.58 & \multirow{2}{*}{$\begin{array}{c}x^{2}=11.56 \text { Obs. } \\
3>1 \text { e } 2(p=0.003)\end{array}$} \\
\hline & & 1 & 1 & 2 & \\
\hline
\end{tabular}

Distal control

\begin{tabular}{|c|c|c|c|c|c|}
\hline \multirow{2}{*}{ Displacement } & $x^{-}$ & 1.75 & 1.83 & 1.67 & \multirow{2}{*}{$\begin{array}{c}x^{2}=3.00 \\
(p=0.223) N S\end{array}$} \\
\hline & $\mathrm{Mi}$ & 2 & 2 & 2 & \\
\hline \multirow{2}{*}{$\begin{array}{l}\text { Radiographic } \\
\text { union }\end{array}$} & $x^{-}$ & 0.5 & 1.17 & 1.25 & \multirow{2}{*}{$\begin{array}{c}x^{2}=11.84 \text { Obs. } \\
3>1 \text { e } 2(p=0.003)\end{array}$} \\
\hline & $\mathrm{Mi}$ & 0 & 1 & 2 & \\
\hline \multirow{2}{*}{ Integration } & $x^{-}$ & 0.58 & 1.17 & 1.42 & \multirow{2}{*}{$\begin{array}{c}x^{2}=10.30 \text { Obs. } \\
3>1 \text { e } 2(p=0.006)\end{array}$} \\
\hline & & 0 & 1 & 2 & \\
\hline
\end{tabular}

Legend: $x$-: mean - Mi: median - NS: not significant Sources: DOT. UNIFESP-EPM UNIVÁS-FACIMPA.

As suggested by other authors, a drop of the adhesive was place on each osteotomy, in the direction from dorsal to ventral, so as to allow bone formation around the adhesive ${ }^{(20,21)}$.

The operation made it impossible for the animals to walk until the seventh day after the operation. From then onwards, they started to slowly improve, supporting themselves on their operated limbs. Transmission of mechanical force through the osteotomies is important in order to minimize the effect of disuse, thereby positively influencing the rate, degree and efficacy of the repair and the remodeling of the bone graft. When bone grafts are placed in soft tissue without being subjected to stress, they tend to be reabsorbed ${ }^{(1,22,23)}$. In some animals, diffuse edema in the front paws was observed on the day after the operation, which ceased spontaneously after around 10 days, as also observed by other authors ${ }^{(8)}$.

Ten animals were replaced: six because of fractures 
Table 4 - Proximal and distal osteotomies according to three observers' readings of displacement, radiographic union and integration of bone grafts with adhesive and without adhesive (control), in group D (16 weeks).

\begin{tabular}{|c|c|c|c|c|c|}
\hline \multicolumn{2}{|c|}{$\begin{array}{l}\text { Proximal with } \\
\text { adhesive }\end{array}$} & \multirow{2}{*}{\begin{tabular}{|c|} 
Obs. 1 \\
1.83 \\
\end{tabular}} & \multirow{2}{*}{\begin{tabular}{|c|} 
Obs. 2 \\
2 \\
\end{tabular}} & \multirow{2}{*}{$\begin{array}{c}\text { Obs. } 3 \\
2 \\
\end{array}$} & \multirow{3}{*}{$\begin{array}{c}\begin{array}{c}\text { Friedman's analysis } \\
\text { of variance }\end{array} \\
\mathrm{x}^{2}=4.00 \\
(\mathrm{p}=0.135) \mathrm{NS}\end{array}$} \\
\hline \multirow{2}{*}{ Displacement } & $x^{-}$ & & & & \\
\hline & $\mathrm{Mi}$ & 2 & 2 & 2 & \\
\hline \multirow{2}{*}{$\begin{array}{l}\text { Radiographic } \\
\text { union }\end{array}$} & $x^{-}$ & 0.25 & 1.67 & 1.75 & \multirow{2}{*}{$\begin{array}{c}x^{2}=22.17 \text { Obs. } \\
2 \text { e } 3>1(p=0.000)\end{array}$} \\
\hline & $\mathrm{Mi}$ & 0 & 2 & 2 & \\
\hline \multirow{2}{*}{ Integration } & $x^{-}$ & 0.58 & 1.83 & 1.92 & \multirow{2}{*}{$\begin{array}{c}x^{2}=17.43 \text { Obs. } \\
2 \text { e } 3>1(p=0.000)\end{array}$} \\
\hline & & 0 & 2 & 2 & \\
\hline
\end{tabular}

\begin{tabular}{|c|c|c|c|c|c|}
\hline \multicolumn{6}{|c|}{ Proximal control } \\
\hline \multirow{2}{*}{ Displacement } & $x^{-}$ & 1.92 & 2 & 1.92 & \multirow{2}{*}{$\begin{array}{c}x^{2}=1.00 \\
(p=0.607) N S\end{array}$} \\
\hline & $\mathrm{Mi}$ & 2 & 2 & 2 & \\
\hline \multirow{2}{*}{$\begin{array}{l}\text { Radiographic } \\
\text { union }\end{array}$} & $x^{-}$ & 0.67 & 1.58 & 1.92 & \multirow{2}{*}{$\begin{array}{c}x^{2}=17.11 \text { Obs. } \\
3>1 \text { e } 2(p=0.000)\end{array}$} \\
\hline & Mi & 1 & 2 & 2 & \\
\hline \multirow{2}{*}{ Integration } & $x^{-}$ & 1 & 1.67 & 1.92 & \multirow{2}{*}{$\begin{array}{c}x^{2}=12.24 \text { Obs. } \\
3>1 \text { e } 2(p=0.002)\end{array}$} \\
\hline & & 1 & 2 & 2 & \\
\hline
\end{tabular}

\begin{tabular}{|c|c|c|c|c|c|}
\hline \multicolumn{6}{|c|}{ Distal with adhesive } \\
\hline \multirow{2}{*}{ Displacement } & $x^{-}$ & 1.92 & 2 & 2 & \multirow{2}{*}{$\begin{array}{c}x^{2}=2.00 \\
(p=0.368) N S\end{array}$} \\
\hline & Mi & 2 & 2 & 2 & \\
\hline \multirow{2}{*}{$\begin{array}{l}\text { Radiographic } \\
\text { union }\end{array}$} & $x^{-}$ & 0.83 & 1.67 & 1.75 & \multirow{2}{*}{$\begin{array}{c}x^{2}=13.79 \text { Obs. } \\
3>1 \text { e } 2(p=0.001)\end{array}$} \\
\hline & Mi & 1 & 2 & 2 & \\
\hline \multirow{2}{*}{ Integration } & $x^{-}$ & 1.08 & 1.75 & 1.92 & \multirow{2}{*}{$\begin{array}{c}x^{2}=9.50 \text { Obs. } \\
3>1 \text { e } 2(p=0.009)\end{array}$} \\
\hline & & 1 & 2 & 2 & \\
\hline \multicolumn{6}{|l|}{ Distal control } \\
\hline \multirow{2}{*}{ Displacement } & $x^{-}$ & 2 & 2 & 2 & \multirow{2}{*}{ No need for analysis } \\
\hline & $\mathrm{Mi}$ & 2 & 2 & 2 & \\
\hline \multirow{2}{*}{$\begin{array}{l}\text { Radiographic } \\
\text { union }\end{array}$} & $x^{-}$ & 1.58 & 1.83 & 1.92 & \multirow{2}{*}{$\begin{array}{c}x^{2}=3.88 \\
(p=0.144) N S\end{array}$} \\
\hline & $\mathrm{Mi}$ & 2 & 2 & 2 & \\
\hline \multirow{2}{*}{ Integration } & $x^{-}$ & 1.58 & 1.83 & 2 & \multirow{2}{*}{$\begin{array}{c}x^{2}=6.62 \text { Obs. } \\
3>1 \text { e } 2(p=0.037)\end{array}$} \\
\hline & & 2 & 2 & 2 & \\
\hline
\end{tabular}

Legend: x-: mean - Mi: median - NS: not significant

Sources: DOT. UNIFESP-EPM UNIVAS-FACIMPA.

(which occurred on the control side in five animals and on both sides in one animal); and four because of deep infection with compromising of their general state (two on the side with adhesive and two on the control side). Although the number of animals that suffered fractures was small, the fact that these occurred in greater number on the control side suggests that the radius with a bone graft and adhesive was able to bear greater weight, thus sparing the ulna from axial loads.

The anti-infection power of butyl-2-cyanoacryla$\mathrm{te}^{(17)}$ was not confirmed, since no significant difference in relation to infection was found between the side with adhesive and the control.

On macroscopic examination, deformity of the surgical specimens was observed in the animals in groups $\mathrm{A}$ and $\mathrm{B}$, without any significant difference between the side with adhesive and the control side. In the other two groups $(\mathrm{C}$ and $\mathrm{D})$, no deformity
Table 5 - Displacement, radiographic union and integration of bone grafts after 2, 4, 8 and 16 weeks (groups A, B, C and D), with adhesive and without adhesive (control), in the proximal and distal osteotomies, according to the mean scores. Wilcoxon's test ( $z$ and $p)$.

\begin{tabular}{l|c|c|c|c|c|c|c|c}
\hline \multicolumn{7}{c}{ Displacement of bone graft } \\
\hline & \multicolumn{3}{|c}{ Proximal osteotomy } & \multicolumn{3}{c}{ Distal osteotomy } \\
\hline & Adhesive & Control & zcalc. & $\mathbf{p}$ & Adhesive & Control & zcalc. & $\mathbf{p}$ \\
\hline Group A & 1.25 & 0.67 & -2.33 & 0.02 & 1.83 & 1.5 & -1.63 & 0.1 \\
\hline Group B & 1.42 & 1.58 & -0.81 & 0.41 & 1.92 & 1.75 & -0.81 & 0.41 \\
\hline Group C & 1.5 & 1.17 & -1.41 & 0.15 & 1.92 & 1.67 & -1.34 & 0.18 \\
\hline Group D & 2 & 1.92 & -1 & 0.31 & 2 & 2 & 0 & 1 \\
\hline
\end{tabular}

\begin{tabular}{c|c|c|c|c|c|c|c|c}
\hline \multicolumn{7}{c|}{ Radiographic union of bone graft } \\
\hline & \multicolumn{3}{|c|}{ Proximal osteotomy } & \multicolumn{3}{c}{ Distal osteotomy } \\
\hline & Adhesive & Control & zcalc. & $\mathbf{p}$ & Adhesive & Control & zcalc. & $\mathbf{p}$ \\
\hline Group A & 0.33 & 0.08 & -1.34 & 0.18 & 0.33 & 0 & -1.63 & 0.1 \\
\hline Group B & 0 & 0 & 0 & 1 & 0.33 & 0.67 & -1 & 0.31 \\
\hline Group C & 1.33 & 0.58 & -2.12 & 0.03 & 1.42 & 1.25 & -0.55 & 0.57 \\
\hline Group D & 1.75 & 1.92 & -1.41 & 0.15 & 1.75 & 1.92 & -1.41 & 0.15 \\
\hline
\end{tabular}

Integration of bone graft

\begin{tabular}{l|c|c|c|c|c|c|c|c}
\hline & \multicolumn{3}{|c|}{ Proximal osteotomy } & \multicolumn{3}{c}{ Distal osteotomy } \\
\hline & Adhesive & Control & zcalc. & $\mathbf{p}$ & Adhesive & Control & zcalc. & $\mathbf{p}$ \\
\hline Group A & 0 & 0 & 0 & 1 & 0.62 & 0.29 & -0.82 & 0.41 \\
\hline Group B & 0 & 0.08 & -1 & 0.31 & 0.25 & 0.33 & -1 & 0.31 \\
\hline Group C & 0.92 & 0.5 & -2.24 & 0.02 & 1.58 & 1.42 & -0.74 & 0.45 \\
\hline Group D & 1.92 & 1.92 & 0 & 1 & 1.92 & 2 & -1 & 0.31 \\
\hline Sources: DOT. UNIFESP-EPM UNIVÁS-FACIMPA.
\end{tabular}

was seen, probably because of bone remodeling that occurred during the consolidation of the osteotomies, as also observed by other authors ${ }^{(8)}$.

After four weeks, the bone graft was stable upon manipulation, in all the surgical specimens, in the same way as observed by other authors ${ }^{(22)}$. Absence of movement upon manipulation is considered to be one of the clinical criteria for diagnosing union of the osteotomies $^{(24)}$. The adhesive did not interfere with the clinical consolidation process of the osteotomies up to this observation time.

Polymerization of the adhesive occurred after around 30 seconds, and there was no change in adhesive color from blue to white, which was observed by some other authors ${ }^{(2,19,25)}$.

Remains of adhesive were found in $100 \%$ of the animals. Thus, a longer observation period will be necessary in order to determine the time taken for the adhesive and its action on tissues to be eliminated. It has been recognized that esters with greater numbers of carbon atoms degrade slowly, and some authors have suggested that complete removal of the adhesive may never be attained ${ }^{(6,7,15,17,20,26)}$. 
It was observed in analyzing the radiographs that the adhesive was responsible for lower deviation of the bone graft in proximal osteotomies with adhesive, after two weeks of observation $(p=0.02$; Table 5), as also seen by other authors, who found that the bone fragments were kept in position through using cyanoacrylate adhesive, even though the animals supported themselves early on, with the operated $\operatorname{limb} b^{(3,25,27,28)}$. These results are also concordant with in vitro observations, which showed that butyl-2-cyanoacrylate presented high initial adhesive resistance ${ }^{(2,14)}$.

It was observed that the radiographic union was best in the proximal osteotomies with adhesive in group $\mathrm{C}(\mathrm{p}=0.03$; Table 5$)$.

By the $16^{\text {th }}$ week, it was found that most of the osteotomies presented union, without any significant difference between the adhesive and control groups. This was not in agreement with some other authors, who observed that all the osteotomies reached consolidation between three and eight weeks after the operation $^{(22,29,30)}$.

Radiographic integration of the bone graft with the bone ends occurs when then there is continuity of the cortex and medullary canal, absence of the osteotomy line and presence of a mineralized bone callus, i.e. structural and functional interlinking between an organized bone and the graft ${ }^{(25)}$.

The integration of the bone graft was better in the proximal osteotomies with adhesive, in group $\mathrm{C}$ $(p=0.02$; Table 5). Integration of most of the bone grafts also occurred by the $16^{\text {th }}$ week of observation, without any statistically significant difference between the adhesive and control groups.

Integration of autologous cortical bone grafts of the diaphysis of the radius and ulna were observed on radiographs in other studies after six and sixteen we$\mathrm{eks}^{(22,31)}$. Although there is a close relationship between revascularization of the bone graft and its integration, it was shown that incorporation of the cortical bone graft was not expected, even when fixed in a stable manner to a healthy bed, with good vascularization. Even under these excellent conditions, the incorporation process was complex and controlled by multiple factors, such that it might continue for months ${ }^{(32)}$.

The proximal osteotomies with adhesive showed less deviation of the bone graft after two weeks, and greater proportions of union and integration of bone grafts after eight weeks. This suggests that good adap- tation and stability of the bone graft in the receptor bed were important for this result ${ }^{(13)}$.

The adult age of these animals, along with the more rigorous radiographic criterion for considering results to poor in the two radiographic views, may have contributed towards slower attainment of bone union and bone graft integration than reported in the literature.

There were no occurrences of fractures in the bone graft in any of the animals. The probable cause of the ulnar fractures was mechanical overload due to the axial forces that the ulna had to bear, without any significant difference between the adhesive and control sides. The ulna mainly bears transverse shearing forces, while the radius bears axial loads ${ }^{(8)}$.

The radiographic analysis on the bone callus of each of the osteotomies was impaired because of formation of a single bone callus. However, this did not impair the analysis on the union of the osteotomies since it was concluded based on analysis of tibial fractures in adult rabbits ${ }^{(33)}$ that the orthopedist and radiologist did not have a secure basis for radiographically diagnosing fracture consolidation. The radiographic size of the bone callus is a poor prognostic factor in relation to the resistance of the fracture union. Reestablishment of resistance and rigidity after a fracture is more related to the quantity of new bone joining the bone fragments than to the quantity of bone callus ${ }^{(23)}$.

\section{CONCLUSIONS}

The adhesive was not completely metabolized, 16 weeks after the operation.

Clinical consolidation of the osteotomies was achieved in four weeks.

The adhesive stabilized the bone graft over the first two weeks.

The adhesive did not interfere with consolidation of the osteotomies, or with integration of the bone grafts, after 16 weeks of radiographic observation.

\section{ACKNOWLEDGEMENTS}

To Yara Juliano and Neil Ferreira Novo, Titular Professors of Public Health at UNISA, for the statistical analysis.

To the radiologists Prof. Flávio Galvão Lima and Michelaine de Freitas Vasconcelos Gomes Nogueira, and to the orthopedist Paulo Calafiori Resende, for analysis of the radiographs. 


\section{REFERENCES}

1. Friedlaender GE. Bone grafts. The basic science rationale for clinical applications. J Bone Joint Surg Am. 1987;69(5):786-90.

2. Kilpikari J, Lapinsuo $M$, Törmälä $P$, Pätiälä $H$, Rokkanen $P$. Bonding strength of alkyl-2-cyanoacrylates to bone in vitro. J Biomed Mater Res. 1986;20(8):1095-102.

3. Meyer G, Muster D, Schmitt D, Jung P, Jaeger JH. Bone bonding through bioadhesives: present status. Biomater Med Devices Artif Organs. 1979;7(1):55-71.

4. Amarante MT, Constantinescu MA, O'Connor D, Yaremchuk MJ. Cyanoacrylate fixation of the craniofacial skeleton: an experimental study. Plast Reconstr Surg. 1995;95(4):639-46.

5. Nathan HS, Nachlas MM, Solomon RD, Halpern BD, Seligman AM. Nonsuture closure of arterial incisions using a rapidly-polymerizing adhesive. Ann Surg. 1960;152:648-59.

6. Matsumoto T, Hardaway RM 3rd, Heisterkamp CA 3rd, Pani KC, Leonard F. Higher homologous cyanoacrylate tissue adhesives in surgery of internal organs. Arch Surg. 1967;94(6):861-4.

7. Hunter KM. Cyanoacrylate tissue adhesive in osseous repair. Br J Oral Surg 1976;14(1):80-6.

8. Ignácio $\mathrm{H}$, Masser $\mathrm{N}$, Barbieri $\mathrm{CH}$, Chierici $\mathrm{G}$. Uso da poliuretana derivada de óleo de mamona para preencher defeitos ósseos diafisários segmentares do rádio. Estudo experimental em coelhos. Rev Bras Ortop. 1997;32(10):815-21.

9. Weber SC, Chapman MW. Adhesives in orthopaedic surgery. A review of the literature and in vitro bonding strengths of bone-bonding agents. Clin Orthop Relat Res. 1984;(191):249-61

10. Phemister DB. The fate of transplanted bone and regenerative power of its various constituents. Surg Obstet Gynecol. 1914;19:303-33.

11. Gray JC, Elves MW. Early osteogenesis in compact bone isografts: a quantitative study of contributions of the different graft cells. Calcif Tissue Int. 1979;29(3):225-37.

12. Harris WH, Haywood EA, Lavorgna J, Hamblen DL. Spatial and temporal variations in cortical bone formation in dogs. J Bone Joint Surg Am. 1968;50:1118-28.

13. Stevenson S. Enhancement of fracture healing with autogenous and allogeneic bone grafts. Clin Orthop Relat Res. 1998;(355 Suppl):S239-46.

14. Brauer GM, Kumpula JW, Termini DJ, Davidson KM. Durability of the Bond between bone and various 2-cyanoacrylates in an aqueous environment. J Biomed Mater Res. 1979;13(4):593-606.

15. Toriumi DM, Raslan WF, Friedman M, Tardy ME. Histotoxicity of cyanoacrylate tissue adhesives. A comparative study. Arch Otolaryngol Head Neck Surg. 1990;116(5):546-50.

16. Ciapetti G, Stea S, Cenni E, Sudanese A, Marraro D, Toni A, et al. Toxicity of cyanoacrylates in vitro using extract dilution assay on cell cultures. Biomaterials. 1994;15(2):92-6.

17. Lehman RA, Hayes GJ, Leonard F. Toxicity of alkyl 2-cyanoacrylates. I. Peripheral nerve. Arch Surg. 1966;93(3):441-6.
18. Cameron JL, Woodward SC, Pulaski EJ, Sleeman HK, Brandes G, Kulkarni RK, Leonard F. The degradation of cyanoacrylate tissue adhesive. I. Surgery. 1965;58:424-30.

19. Schnieder EA. Experiences with tissue adhesives in middle ear operations. ORL J Otorhinolaryngol Relat Spec. 1972;34(4):227-39.

20. Harper MC, Ralston M. Isobutyl 2-cyanoacrylate as an osseous adhesive in the repair of osteochondral fractures. J Biomed Mater Res. 1983;17(1):167-77.

21. Hampel NL, Pijanowski GJ, Johnson RG. Effects of isobutyl-2-cyanoacrylate on bone healing. Am J Vet Res. 1986;47(7):1605-10.

22. Holden CE. The role of blood supply to soft tissue in the healing of diaphyseal fractures. An experimental study. J Bone Joint Surg Am. 19721;54(5):993-1000.

23. Panjabi MM, White AA 3rd, Wolf JW Jr. A biomechanical comparison of the effects of constant and cyclic compression on fracture healing in rabbit long bones. Acta Orthop Scand. 1979;50(6 Pt 1):653-61.

24. Vihtonen K, Vainionpää $S$, Mero $M$, Pätiälä H, Rokkanen $P$, Kilpikari J, et al. Fixation of experimental osteotomies of the distal femur in rabbits with bone cement and cyanoacrylate. Arch Orthop Trauma Surg. 1986;105(3):133-6.

25. Borges APB, Rezende CMF, Sampaio R, Oliveira HP, Ponpermayer LG. Emprego de adesivo butil-2-cianoacrilato na fixação de esquírolas em fraturas de fêmur de cães. Aspectos radiológicos. Arq Bras Med Vet Zootec. 1992;44(1):29-41.

26. Pani KC, Gladieux G, Brandes G, Kulkarni RK, Leonard F. The degradation of n-butyl alpha-cyanoacrylate tissue adhesive. II. Surgery. 1968;63(3):481-9.

27. Papatheofanis FJ, Ray RD. Experimental use of adhesives in the repair of transverse fractures of the rat and rabbit. Biomater Med Devices Artif Organs. 1983;10(4):247-65.

28. Xavier MSV, Souza VCT, Gomes PO, Corrêa JC, Novo NF, Juliano Y. Efeito do enxerto autólogo de pericôndrio costal com butil-2-cianoacrilato em lesão provocada na cartilagem articular do joelho de coelhos. Acta Cir Bras [serial online] 1999;14(4). Disponível em:: URL: http://www.scielo.br/acb.

29. Papatheofanis FJ. Surgical repair of rabbit tibia osteotomy using isobutyl-2-cyanoacrylate. Arch Orthop Trauma Surg. 1989;108(4):236-7.

30. Janowski EM, Mazer N, Barbieri CH, Gonçalves RP. The effect of venous occlusion on the integration of vascularized cortical bone graft. J Reconstr Microsurg. 1993;9(3):219-25.

31. Mehra V, Gill SS, Dhillon MS, Bhusnurmath SR, Nagi ON. Comparison of fresh autogenous with formalin preserved allogeneic bone grafts in rabbits. An experimental study. Int Orthop. 1993;17(5):330-4.

32. Stevenson S, Li XQ, Davy DT, Klein L, Goldberg VM. Critical biological determinants of incorporation of non-vascularized cortical bone grafts. Quantification of a complex process and structure. J Bone Joint Surg Am. 1997;79(1):1-16

33. Nicholls PJ, Berg E, Bliven FE Jr, Kling JM. X-ray diagnosis of healing fractures in rabbits. Clin Orthop Relat Res. 1979;(142):234-6. 